\title{
Aspects of translating gender
}

\section{Uwe Kjær Nissen (University of Southern Denmark)}

\begin{abstract}
:
Aspects of translating gender

Grammatical gender and the related concept, 'social gender', are important linguistic categories which, in this article, are used to illustrate that the translation process is not only a 'cross-cultural transfer' but also a cross-ideological transfer. By departing from the view that different languages reflect different ways of perceiving reality, it is argued here that the linguistic structure of languages with regard to gender (i.e. grammatical vs. pronominal gender), as well as different connotations of gender, have a considerable influence upon the translation process and, hence, on how the reader of the target language is meant to perceive reality. The article emphasizes the importance of the translator's role in analyzing gender aspects in the source text and determining the ideological impact gender connotations may have in both the source and the target text.
\end{abstract}

\section{$1 \quad$ Introduction}

Although translation has been described as a "cross-cultural transfer"1 (Vermeer 1986), it is important to note that this transfer implies an ideological transfer as well, if ideology is understood in its broad sense, i.e. as the standard set of values, ideas and beliefs that govern a community, and, consequently, a translator must possess in-depth knowledge of the ideas, beliefs, and values that connect to the languages being translated. By means of different, but interrelated linguistic categories of gender (grammatical, pronominal and, especially, social gender), I intend to illustrate in this article to what extent ideological considerations play a role if the translation takes place between languages that structurally differ with respect to these categories.

\footnotetext{
* I am grateful to two anonymous referees for valuable comments.

${ }^{1}$ It should be noted that the culturally oriented approach to translation theory has, for various reasons, mainly been applied to more pragmatic texts (cf. Snell-Hornby 1990: 84). However, in this article the basic considerations will be applied to literary translations.
} 


\section{Grammatical and pronominal gender}

It is generally accepted that languages can be classified according to whether they show grammatical gender or not $^{2}$. The determining criterion of gender is agreement, and saying that a specific language has, for example, two genders implies that there are two classes of nouns, which can be distinguished syntactically, according to the agreements they take. Thus, the definition of agreement itself becomes important but, in the vast literature on gender, there seems to be no unanimous acceptance of what agreement means (cf. Corbett 1991: ch. 5) and a bone of contention is often whether or not agreement includes the control of anaphoric pronouns by their antecedent, e.g. the husband ... he. According to Corbett, languages in which pronouns present the only evidence for gender are to be included in grammatical gender languages but, as this approach is not generally accepted, he prefers to label them 'pronominal gender systems ${ }^{\prime 3}$ (1991: 5). Hence, in the following discussion, I will distinguish between languages that show grammatical gender (e.g. German and Spanish) and languages that show pronominal gender (e.g. Danish and English) ${ }^{4}$. However, one has to bear in mind that the former grammatical gender languages (German and Spanish) also show pronominal gender.

With respect to human beings - and contrary to what is the case with inanimate nouns gender is most frequently not assigned arbitrarily. Rather, as in Spanish and German, there is considerable overlap between grammatical gender and the sex of the person referred to. In fact, apart from so-called generic reference (where the masculine form refers to both women and men), most feminine nouns denoting human beings refer to females and most masculine nouns denoting human beings refer to males ${ }^{5}$. Therefore, in most cases the transfer from a language that shows pronominal gender to a language that shows grammatical gender does not constitute a technical problem. For instance, Danish fader or English father are easily transferred to the masculine gender in, say, Spanish el padre or German der Vater, as long as speakers of the four languages involved interpret the concept of 'father' in the same way.

When a language that shows grammatical gender marks gender syntactically in a way unavailable to a pronominal gender language, difficulties may arise for the translator as to

\footnotetext{
${ }^{2}$ Although I am aware that, over the past few decades of language and gender studies, the term 'sex' has been substituted, for various reasons, by the term 'gender', in this article I will reserve 'gender' for the linguistic category and 'sex' for the biological classification.

${ }^{3}$ In many cases this denomination is equivalent to so-called 'natural gender systems'. However, as grammatical gender systems also contain, more often than not, some natural criteria for their noun classification and, as natural gender systems are far from being 'natural' (cf. e.g. English feminine pronoun selection when referring to a ship), the term employed by Corbett, 'pronominal gender', seems much more appropriate.

${ }^{4}$ Although Danish distinguishes two genders, neutrum and genus commune, it is included in the latter group because reference to the sex of the person referred to in most cases is achieved by means of pronominal reference. For this reason, I include Danish in the group of languages that show pronominal reference, although, strictly speaking, this is not true.

${ }^{5}$ For Geman see e.g. Hellinger (1990) and for Spanish see e.g. Nissen (2002).
} 
how to supply the information about the sex of the person in question. In the first line of the following stanza of the poem Ninguneo, 'Nobodying', by the Mexican writer Rosario Castellanos, the first person reference hago ('I do') could refer, in theory, to a woman or a man but, already, in the second line, this ambiguity is resolved, as the predicate construction reveals the sex of the referent:

¿qué diablos hago aquí en la Ciudad Lux, presumiendo de culta y de viajada sino aplazar la ejecución de una sentencia que ha caído sobre mí?

Languages that do not mark gender in predicate constructions must, naturally, resort to other methods to supply the reader with the necessary information, in this case, about the sex of the protagonist in the poem:

What the devil am I doing here in the City of Lights

putting on the airs of a cultured and well-traveled woman

but simply postponing the execution of a

sentence that has been pronounced upon me?

(cit. in Ahern, 1989: 58)

Apart from extending the line by adding a word and, consequently, changing the rhythm of the stanza, the translator has also slightly altered the focus of interest compared to the original text. Whereas the Spanish original focuses on 'I (type: woman) + cultured/well-traveled', the English translation focuses on 'I + woman (type: cultured/well-traveled)'. A back-translation from English to Spanish would, most probably, prompt: mujer [= woman] culta y viajada. In this way, this translation procedure not only adds the necessary information but, at the same time, also intensifies the focus on the fact that the referent is a female. Therefore, an apparently 'innocent' supply of information may distort the text in a way that was not intended. Seen from an ideological perspective, the English reader in this case might interpret the stanza to be more related with 'women's matters' or even 'feminism' than was originally intended. Similar problems may occur in many other cases, in fact, everywhere where the source language, by means of agreement structures, operates differently from the target language, that is in connection with noun-modifications, pronoun uses, pronominal references, and so forth.

An interesting phenomenon that may affect languages which show grammatical gender occurs in connection with the translation of certain occupational titles. In these (few) cases, and due to societal circumstances (see also section 3), the gender of a given title may be switched to another gender. For example, Beier (1982) suggests switching the masculine gender of the German occupational title der Hutmacher ('the hatmaker', masc.) to the feminine gender of the Spanish title la sombrerera (fem.). The reason for this is that this profession is generally occupied by women in Spain. 
It is suggested, in defiance of the shift of gender from German to Spanish, to use sombrerera for the generic occupational title and to use sombrerero only if the realworld object, i.e. the person carrying this denomination, is a male. (Beier 1982: 103 104 , my translation).

While this procedure may be quite appropriate for translations of pragmatic texts (such as job advertisements), it is probably less appropriate for literary texts, where the culture of the source language is, or at least should be, more prominent.

\subsection{Connotations of gender}

Although, from a technical point of view, gender marking is much easier to cope with if the translation occurs between languages that both show gender, the translation process may give rise to other problems as a result of the connotations gender as such conveys ${ }^{6}$ and, hence, also as a result of the divergent ways in which speakers may perceive the world. This is especially true with respect to metaphors and personifications, and an ideologically determined clash may occur if a specific gender in one language connotes certain properties, while the translated word in the target language belongs to another gender that conveys quite different connotations. The following quote from Roman Jacobson will suffice to exemplify this problem:

The Russian painter Repin was baffled as to why Sin had been depicted as a woman by German artists; he did not realize that "sin" is feminine in German (die Sünde), but masculine in Russian (грех). Likewise a Russian child, while reading a translation of German tales, was astounded to find that Death, obviously a woman (Russian смерть, fem.) was pictured as an old man (German der Tod, masc.). My sister Life, the title of a book of poems by Boris Pasternak, is quite natural in Russian, where 'life' is feminine (Жизнь), but was enough to reduce to despair the Czech poet Josef Hora in his attempt to translate these poems, since in Czech this noun is masculine (život). (1959: 237)

Similarly, the German painter Stuck personified the gruesome war as a man (der Krieg, masc.) while, in contrast, the Polish painter Grotger represented a similar war-like figure as a woman (wojna, fem.) (de Courtenay, 1929: 246). Both references show that the translation of gender is not an 'innocent' task, but a very complicated process that has to take into account the fact that one word of one specific gender reflects one reality in one language, while the corresponding word that possesses the opposite gender may reflect another reality.

Naturally, problems of this kind are difficult to cope with, but from a technical point of view and despite the apparent semantic connotations of the gender of (some) words - there are, at least, three possible ways to mitigate the conflicts noted above.

\footnotetext{
${ }^{6}$ For details about connotations on gender, see e.g. Ervin (1962).
} 
In the first place, one might look for a synonym that belongs to the same gender as the source word. This method has been chosen in the following example, taken from a pragmatic text. It also demonstrates that the connotations of gender may play a decisive role in advertising. Thus, the German slogan used by the petrol company 'Esso' Pack den Tiger in den Tank (literal translation: 'Put the tiger into the petrol tank.') could not be translated directly into Italian, as the masculine gender of the German word, der Tiger, does not correspond with the gender of the Italian counterpart, la tigre (fem.). Presumably, because the feminine word could not connote the 'power' and 'energy' the masculine gender supposedly conveys (at least in traditional Western society), the advertising company chose to use another, albeit related animal, il leopardo (masc.) (Kalverkämper 1979: 61). Evidently, what is at stake here is not a faithful zoological translation, but the connotations a word of a specific gender conveys and the images these connotations will evoke. In this way, the substitution (der Tiger $\rightarrow$ il leopardo) is based upon sex-stereotypical ideas which reflect the ideological aspects involved in the translation process.

Secondly, one might select a word from a third language that corresponds with the gender of the word in the source text. In this case, obviously, the chosen word must somehow be familiar to the reader. Wandruszka gives an instructive example: the text establishes a sexbased opposition between the male (!) God of the $\mathrm{Sun}^{7}$ and the feminine moon (being the 'sister' of the sun). However, in German sun is feminine and moon is masculine: just the opposite of what is intended. To make matters worse, the moon is later on to be pronominalized by the feminine relative pronoun sie ('that' [='she']). Obviously, grammatical agreement would fail if the German word for 'moon' der Mond were used. One solution, therefore, is to resort to another language. In this case, the Latin language is employed and the equivalent words sol and luna are introduced:

... der unbesiegbare mediterrane Sonnengott, Sol invictum, und seine sanfte Schwester Luna, die die lauen Nächte erhellen (1991: 31)

(... the invincible Mediterranean God of the Sun, Sol invictum, and his tender sister Luna that enlightens the gentle nights.)

By this procedure, both genders are switched, but the binary system that is to indicate a sexbased opposition is maintained.

Thirdly, and perhaps as a last resort, the target text could be provided with a footnote indicating the divergent gender of the word in question in the source language. In this case, however, we have to assume that the reader is capable of making this 'gender-switch', of assigning a different connotative meaning to a word that traditionally has another.

\footnotetext{
${ }^{7} \mathrm{I}$ am aware of the fact that the masculine article der determines Gott (which is a masculine word) and not Sonne; this fact, however, does not invalidate Wandruszka's procedure of establishing a binary system that is contrary to the gender of the German words.
} 


\section{Social gender}

The previous section has shown some difficulties that may arise due to the cultural transfer of gender where the sex of the referent was known or presumed known in conection with metaphors and personifications. This section will focus on translations where the sex of the referent is unknown or, perhaps, not relevant.

In connection with occupational titles, it is common for speakers of languages that show pronominal gender not to select anaphoric pronouns arbitrarily. Thus, usually, a Danish speaker, for instance, will pronominalize dommer ('judge') with han ('he'), and, similarly, an English speaker 'lawyer' with 'he', whereas other professions usually trigger the feminine pronominal counterpart: Danish: sekretaren ... hun ('the secretary ... she') or English: 'the kindergarten teacher ... she'. Everyday dialogues illustrate this phenomenon:

- My nurse told me to take five pills a day.

- Well, she should know, shouldn't she?

and, similarly:

- I went to the dentist yesterday. What a day!

- What did he say?

- Well, she said that if I go on like this, I'll be in need of false teeth very soon.

In his book Semantics, Lyons raises the following questions in an attempt to explain this pattern:

From the statement My cousin is a nurse, however, most speakers of English will infer that the person being referred to is female. Is this inference based upon an implication, which belongs to the sense of 'nurse'? (...) Or is this inference probabilistic, being determined by our knowledge that most nurses, like most secretaries and most students of domestic science or speech therapy, happen to be female? (1977: 310).

Lyons does not supply the reader with a definite answer, but it seems appropriate to assume that the choice of pronoun is based neither on grammatical nor natural criteria as such, but more likely on a stereotypical classification (which may be a consequence of quantitative considerations) according to which certain professions relate to either females or males. Also the next quote, which relates to the Danish language, reflects the sex-biased semantic loading of various job titles:

The occupational denominations lawyer, doctor and head-master belong to a group of words in which no feminine derivation exists. At the same time, and in contradiction to librarian, we are dealing with a group in which women are still today rare; as 
regards these denominations, most Danish speakers [of either sex] would associate them with men. (Gomard 1985: 85, my translation and emphasis).

On the basis of these kinds of stereotypical classifications, Hellinger (1990: 61) defines the term 'social gender' by differentiating two semantic levels:

The features [male/ female] refer to the natural gender of the person referred to; nouns

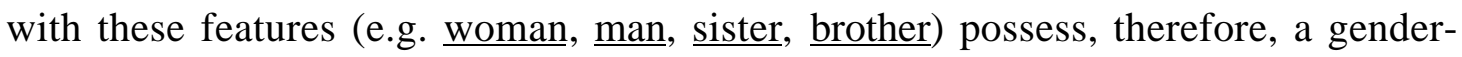
specifying function. Nouns like lawyer or secretary on the contrary, have no genderspecifying function. Nevertheless, often the features 'generally male', 'generally female', respectively, are assigned to these words as a reflection of normative societal conditions." (Hellinger 1990: 61, my translation)

Social gender, then, is the property of a word according to which people assign 'generally male' or 'generally female' ${ }^{\prime}$. It may be worth pointing out that social gender assignment is not bound to any specific occupational title as such, but is dependent on pragmatic and societal considerations. One of these considerations is frequently based upon status. Thus, status explains why most English speakers today will associate the occupational title secretary with a female, whereas the denomination Foreign Secretary or Secretary of State, more often than not will evoke an image of a male.

Another important feature of social gender is its dependency on time. As the assignment of social gender is based on parameters that are determined by society, these parameters may alter due to societal changes. If we return once more to the occupational title, secretary, it may surprise people today to learn that only one century ago this occupation was predominantly executed by men. In the 19th century, then, the social gender of secretary was 'male', i.e. the opposite of what it is today.

A similar case involving the word 'typis' is noted by Lyons (1977: 311):

at the turn of this century $[=1900, \mathrm{UKN}]$ in Britain the expression 'lady typist' was quite commonly employed in contexts (e.g. in advertisements) in which 'typist' would now be used.

The quotation implies that the word 'typist' at the beginning af the $20^{\text {th }}$ century had to be modified by 'lady', because 'typist' without any sex-specific modification referred to men alone. However, during the past 100 years changing social roles have brought about a change in the social gender of the word 'typist', so that now it is no longer necessary to mark the gender with the word 'lady' or 'female'.

\footnotetext{
${ }^{8}$ See also Hellinger and Bußmann (2001-2003: 10-11).
} 


\subsection{Translation problems due to social gender}

Due to its dependency on societal and chronological conditions, the assignment of social gender frequently turns out to be a rather complicated part of the translation process. The following examples ${ }^{9}$ are intended, on the one hand, to demonstrate some ways in which translators have tried to disentangle the problems and, on the other, to show that the choices made imply ideological considerations as well.

In Daphne du Maurier's gothic-like novel Rebecca, the protagonists, Maxim and his wife, have invited some relatives to their once-deserted manor in the English countryside. After dinner, Maxim's brother-in-law expresses his admiration for the meal by saying:

Same cook I suppose, Maxim?

There is no later reference in the book to the cook and the sex of this chef de cuisine is never revealed. How does a translator, whose task it is to translate the sentence into a language that shows grammatical gender, cope with this problem? How does he/she know whether the cook is male or female? There seems to be no one agreed solution as five different translations into grammatical gender languages show:

French: la meme cuisinière

Italian : lo stesso cuoco

Spanish: el mismo cocinero

Portuguese: a mesma cozinheira

German: dieselbe Köchin

(Wandruszka 1969: 173)

The example demonstrates that three translators assigned 'generally female' and two 'generally male' as the social gender of cook. Whether this is due to the translators' lack of knowledge as to what type of cook is more likely to be in a noble English manor or whether this is due to their ideological expectations as to what is likely in their own community, is an open question.

A similar example stems from Bernard Shaw's Back to Methuselah. The original text is as follows:

One of my secretaries was remarking only this morning how well and young I am looking.

\footnotetext{
${ }^{9}$ A number of examples were taken from Mario Wandruszka's "Sprachen - vergleichbar und unvergleichlich" (1969). In the book he systematically compares the translations of a great number of literary works into various European languages.
} 
In this case the translators chose the following solutions:

French: Un de mes secrétaires

Italian: Uno dei miei segretari

Spanish: Una de mis secretarias

Portuguese: Uma das minhas secretárias

German: Einer meiner Sekretäre

(Wandruszka 1969: 174)

Again, the translators disagree: three of them imagined the flatterer to be a male ${ }^{10}$ and two decided the secretary was a female. As no clues are given in the text as to the sex of the referent, the translators have to make their choice in accordance with the knowledge they possess of the source community.

\subsection{Same target language but different output}

The surprising incongruity reflected by the translations above could lead to the assumption that the assignment of social gender depends on the target language as such, perhaps because of its internal structure. However, the next fragment and its translations demonstrate that the target language as such is not crucial, but, rather, the cultural and, hence, ideological assumptions in which the language is 'embedded'.

The modern romance Edge of Dawn written by Maura Seger begins with a description of the preparations for a garden-party dinner:

Since early in the day, the caterer and his staff had been on hand, setting the tables with gleaming china, crystal and silver and beginning preparations for the dinner. (1984: 7, my emphasis)

The caterer, obviously, is a man (due to his), but, as there is no pronominal reference to staff, difficulties arise as to the sex of this group? How are we to know whether the caterer's helpers are females or males or, perhaps, both?

In 1986, two years after the English original had appeared, the novel was translated into Spanish and an edition was published both in Spain and in Mexico. Although Mexican Spanish and Peninsular Spanish are very close (the average reader can easily read books published in one country and vice versa), the Peninsular edition was revised extensively before entering the Mexican market (a process, by the way, editors usually would not undertake with respect to 'decent' literature). The version that was published in Spain begins as follows:

\footnotetext{
${ }^{10}$ Due to the partitive construction, which individualizes the referent, the indefinite pronoun (Un, Uno or Einer) is not likely to be interpreted as a generic reference.
} 
Ya desde por la mañana, muy temprano, el proveedor y sus empleadas [= employees (fem.), UKN] trabajaban alrededor de las mesas... (1986a: 3)

This example demonstrates that the Spanish translator chose to interpret staff to mean females only. In comparison, surprisingly, the Mexican editor assigns just the opposite social gender to the same word:

Desde la mañana, muy temprano, el proveedor y sus empleados [= employees (masc.), UKN] trabajaban colocando la vajilla ... (1986b: 3 )

In this case the caterer's helpers all turn out to be men, or, subsidiarily, both men and women, if we interpret the masculine form as a generic reference. In the latter interpretation, the masculine form leaves the question open, just as was the case in the English original.

Although the above example demonstrates that the assignment of social gender is definitely not language bound ${ }^{11}$, it raises other interesting questions: can we assume that Mexican readers are more likely to imagine both women and men as a caterer's helpers, whereas Spanish readers are more inclined to accept females only in this position? If so, is the translator/editor then accommodating to the readers' expectations instead of to the original text? At this stage, no definite answers can be given, but the examples demonstrate that the assignment of social gender is not an arbitrary process in translation and that decisive ideological aspects are involved.

The next example shows that problems related to the assignment of social gender in translation are not limited to occupational titles alone (although this aspect has most frequently appeared in the linguistic literature ${ }^{12}$ ). The title as such of the book "Naked Came the Stranger" (by Penelope Ashe, New York, 1969) does not reveal whether the reader has to imagine the stranger to be female or male. Nevertheless, as French is a language that shows grammatical gender, the French translator had to make a choice and he opted for the feminine gender: L'étrangere est arrivée nue (Wandruszka 1981: 329). Naturally, although the original title is semantically ambiguous, other indications may reveal the sex of the referent in question: in this case the translator's task was facilitated by the cover photo showing a girl (ibid.).

Also, in the next example, the translator was forced to make a choice (instead of leaving it to the reader her-/himself). Again, I take an example from Wandruszka (1969: 172), who mentions the famous sonnets by Shakespeare, which he dedicated to a 'friend'. His sonnet 104 begins with the line:

To me, fair friend, you never can be old

\footnotetext{
${ }^{11}$ See also the later example from Shakespeare.

${ }^{12}$ For example, Hampares (1976).
} 
Is this invocation addressed to a male or a female? Wandruszka claims (ibid.) that the debate on how to answer this question is still going on and draws attention to two different translations into German from the last century, published within a time span of only six years:

Für mich, Geliebte ... (from 1867, translated by Karl Simrock)

Für mich, Geliebter ... (from 1873, translated by Friedrich Bodenstedt)

The first translation refers to a female, the second to a male. Naturally, if the target language is a language that shows grammatical gender, the translator may be forced to choose one and only one solution ${ }^{13}$ if he/she for reasons of e.g. length or prosody refrains from choosing more generic references like geliebtes Wesen 'beloved creature' or geliebte Person 'beloved person' ${ }^{14}$. Be that as it may, it is clear that problems are involved, and the resolution of which may have important (and perhaps unintended) ideological implications.

We have seen, that, notwithstanding their creative skills, translators more often than not find themselves in a position where they due to the gender structure of the target language have to select one specific option. Whereas e.g. English readers can come to a decision themselves and opt for a unisex solution - that the referent in the book-title or in the sonnet is female and male alike - the readers of the translated text may find a sex-specific solution. The translator, therefore, takes the first important step in giving the word in question an ideological interpretation - even though this is a step that may turn out to be quite decisive in the interpretation of the text as a whole.

\section{Conclusion}

The exposition of some of the problems that arise when translating gender has shown that a variety of parameters are involved when translators have to make their choice of gender. This is especially true of the translation of expressions where the determination of social gender has turned out to be more complex and ambiguous than the selection of expressions which inherently belong to a specific gender.

As a whole, we may conclude that when characterizing translation as a 'cross-cultural transfer' the gender aspects in translation discussed here have shown that this transfer is, in fact, most likely to be understood as a cross-ideological transfer that involves quite a number of parameters, such as historical considerations, societal changes, connotations of gender, sexbiased stereotypical ideas, and the socioeconomic status of the referent. Obviously, for this reason, the translator is in need of in-depth knowledge of the whole range of factors that have a bearing on both the source and the target text. Linguistic categories, like 'gender', may imply

\footnotetext{
${ }^{13}$ It goes without saying that the ubiquitous slash is to be avoided: 'Für mich, Geliebte/r'. This method may be adequate for certain types of texts, e.g. forms, but certainly not for poems.

${ }^{14}$ Both reasonable suggestions by one of the two anonymous referees.
} 
many unpredictable factors in the source text that, even to native speakers, may be opaque ${ }^{15}$, and translators are, therefore, frequently forced to come up with solutions in terms of their own ideologically-based knowledge, possibly supplemented by their own intuitions. The translation of gender, therefore, constitutes a good example for showing that the target text, in comparison with the source text, is always an ideologically enriched text.

\section{References}

Ahern, Maurreen (1989): "Translating Rosario Castellanos". Contrastes 18-19: 47-61.

Beier, Heidrun (1982): "El sombrerero o la sombrerera? Zur Genusneutralisierung femininer Formen bei Berufsbezeichnungen". Fremdsprachen 26 (2): 102-104.

Corbett, Greville (1991): Gender. Cambridge.

de Courtenay, Jan Baudouin (1929): "Einfluss der Sprache auf Weltanschauung und Stimmung". Prace filologiczne 14: 185-256.

Ervin, Susan M. (1962): "The connotations of gender". Word 18: 249-261.

Gomard, Kirsten (1985): "Sexistische Sprachmuster im Dänischen und Tendenzen des sprachlichen Wandels". In: Hellinger, Marlis (ed.): Sprachwandel und feministische Sprachpolitik: Internationale Perspektiven. Opladen: 84-95.

Hampares, Katherine J. (1976): "Sexism in Spanish Lexicography". Hispania 59: 100-109.

Hellinger, Marlis (1990): Kontrastive feministische Linguistik. Mechanismen sprachlicher Diskriminierung im Englischen und Deutschen. Ismaning.

Hellinger, Marlis / Bußmann, Hadumod (2001-2003): Editors introduction to 'Gender across languages. The linguistic representation of women and men' (3 vols.) Amsterdam / Philadelphia. Vol. 1: 1-25.

Jacobson, Roman (1959): "On linguistic aspects of translation". In: Brower, R.A. (ed.): On translation. Cambridge: 232-239.

Kalverkämper, Hartwig (1979): "Quo Vadis Linguistica? - Oder: Der feministische Mumpsismus in der Linguistik". Linguistische Berichte 63: 84-102.

Lyons, John (1977): Semantics (2 vols.). Cambridge.

Nissen, Uwe Kjær (2002): "Gender in Spanish. Tradition and innovation." In: Hellinger, Marlis / Bußmann, Hadumod (eds.): Gender across languages. The linguistic representation of women and men (3 vols.). Amsterdam / Philadelphia: Vol. 2: 251-279.

Seger, Maura (1984): Edge of Dawn. Ontario.

Seger, Maura (1986a): Al filo del amanecer. Madrid.

Seger, Maura (1986b): El precio del triunfo. Mexico.

Snell-Hornby, Mary (1990): "Linguistic transcoding or cultural transfer? A critique of translation theory in Germany". In: Bassnett, Susan / Lefevere, André (eds): Translation, history and culture. London: 79-86.

\footnotetext{
${ }^{15}$ See, for instance, the frequent reference to 'most speakers' in many of the above quotations. Exactly, how many or whom does the author refer to?
} 
Vermeer, Hans J. (1986): "Übersetzen als kultureller Transfer". In: Snell-Hornby, Mary: Übersetzungswissenschaft - Eine Neuorientierung. Zur Integrierung von Theorie und Praxis. Tübingen: 30-53.

Wandruszka, Mario (1969): Sprachen: vergleichbar und unvergleichlich. München.

Wandruszka, Mario (1981): "Unsere Sprachen: instrumentale Strukturen, mentale Strukturen". In: Wills, Wolfram (ed.): Übersetzungswissenschaft. Darmstadt: 323-335.

Wandruszka, Mario (1991): Wer fremde Sprachen nicht kennt ... Das Bild des Menschen in Europas Sprachen. München / Zürich. 